\title{
ARTICLES
}

Submitted 02.02.2015. Approved 06.12.2015

Evaluated by double blind review process. Scientific Editor: Francisco Javier Rondan-Cataluña

DOI: http://dx.doi.org/10.1590/So034-759020160108

\section{COMPARATIVE ANALYSIS OF AMERICAN AND SPANISH CRUISE PASSENGERS' BEHAVIORAL INTENTIONS}

\author{
Análise comparativa das atitudes comportamentais de passageiros de cruzeiro \\ norte-americanos e espanhóis
}

\section{Análisis comparativo de las intenciones de comportamiento de pasajeros de cruceros americanos y españoles}

\begin{abstract}
Earlier studies of cross-national differences in consumer behavior in different consumption sectors have verified that cultural differences have a strong influence on consumers. Despite the importance of cross-national analysis, no studies in the literature examine the moderating effects of nationality on the construction of behavioral intentions and their antecedents among cruise line passengers. This study investigates the moderating effects of nationality on the relationships between perceived value, satisfaction, trust and behavioral intentions among Spanish and (U.S.) American passengers of cruise lines that use Barcelona as home port and port-of-call. A theoretical model was tested with a total of 968 surveys. Structural equation models (SEMs) were used, by means of a multigroup analysis. Results of this study indicated that Spaniards showed stronger relationships between trust and behavioral intentions, and between emotional value and satisfaction. Americans presented stronger relationships between service quality and satisfaction, and between service quality and behavioral intentions.
\end{abstract}

KEYWORDS | Nationality, behavioral intentions, trust, satisfaction, perceived value.

\section{RESUMO}

Estudos em distintos setores de consumo verificaram que as diferenças culturais têm uma forte influência sobre os consumidores. Apesar da importância da análise transnacional, não há estudos na literatura que examinem os efeitos da nacionalidade na construção das intenções de comportamento e seus antecedentes entre os passageiros de cruzeiros. Esta pesquisa investiga os efeitos moderadores da nacionalidade nas relações entre valor percebido, satisfação, confiança e intenções de comportamento entre passageiros espanhóis e norte-americanos. Realizaram-se 968 enquetes para provar o modelo teórico, que foi analisado com modelos de equações estruturais, mediante uma análise multigrupo. Os resultados indicam que os espanhóis mostraram relações mais fortes entre confiança e intenções de comportamento, e entre valor emocional e satisfação. Ao contrário dos norte-americanos, que apresentaram relações mais fortes entre qualidade de serviço e satisfação, e entre qualidade de serviço e intenções de comportamento.

PALAVRAS-CHAVE / Nacionalidade, intenções de comportamento, confiança, satisfação, valor percebido.

ramon.palau@iqs.url.edu Lecturer at Universitat Ramon Llull, Institut Químic de Sarrià - Barcelona, Spain

\section{JAVIER SÁNCHEZ-GARCÍA jsanchez@uji.es Professor at Universitat Jaume I, Departament d'Administració d'Empreses i Màrqueting - \\ Castellón, Spain}

FERNANDO J. GARRIGOS-SIMON fgarrigos@doe.upv.es Professor at Universitat Politècnica de València, Departamento de Organización de Empresas València, Spain

\section{RESUMEN}

Algunos estudios anteriores de diferencias observadas entre países respecto de las conductas de los consumidores de diferentes sectores de consumo verificaron que las diferencias culturales ejercen una poderosa influencia sobre los consumidores. A pesar de la importancia de los análisis transnacionales, no hay en la literatura estudios que analicen los efectos moderadores de la nacionalidad sobre la construcción de intenciones de conducta y sus antecedentes entre pasajeros de cruceros. Este estudio investiga los efectos moderadores de la nacionalidad sobre las relaciones entre el valor percibido, la satisfacción, la confianza y las intenciones de conducta entre los pasajeros españoles y norteamericanos (EE. UU.) de cruceros, que utilizan a Barcelona como puerto de origen y puerto de escala. Se probó un modelo teórico con un total de 968 encuestas. Se emplearon modelos de ecuaciones estructurales (SEM por su sigla en inglés), a través de un análisis multigrupo. Los resultados de este estudio indicaron que los españoles mostraron relaciones más sólidas entre la confianza y las intenciones de comportamiento y entre el valor emocional y la satisfacción. Los americanos evidenciaron relaciones más sólidas entre la calidad del servicio y la satisfacción y entre la calidad del servicio y las intenciones de conducta.

PALABRAS CLAVE / Nacionalidad, Intenciones de conducta, Confianza, Satisfacción, Valor percibido. 


\section{INTRODUCTION}

Between 2005 and 2011, the cruise holidays industry expanded from carrying 14.4 million to 20.6 million cruise passengers worldwide, and from 3.15 to 6.18 million in Europe (European Cruise Council [ECC], 2013). Nevertheless, between 2005 and 2010 there were changes in the market share by continents. North America went from $70 \%$ to $56 \%$, Europe from $21 \%$ to $30 \%$ and the rest of the world from $9 \%$ to $14 \%$. In addition, the Mediterranean has become the second most important destination in the world after the Caribbean (ECC, 2013). In line with this trend, the Port of Barcelona had a total of 2,599,232 cruise passengers, becoming Europe's leading port and the fourth busiest in the world behind Miami, Port Everglades, and Port Canaveral (Port of Barcelona, 2014). Of the total of cruise passengers who embarked and disembarked in the Port of Barcelona, the majority were British, (U.S.) Americans, Spaniards, and Italians. More specifically, American and Spanish cruise passengers, who are culturally different, formed more than $74 \%$ and $20 \%$ respectively of the total of American and Spanish tourists who visited the city of Barcelona in 2011 (Barcelona Tourism, 2011).

In a highly competitive and uncertain context, firms need more than ever to retain customers in view of the benefits associated with loyalty, such as the propensity to expand their relationship in the long term, or acting as motivators among their networks of friends, acquaintances, and family, and other potential customers (McMullan \& Gilmore, 2008). For this reason, the need to know the determinants of customer loyalty has become the fundamental objective in the development of business strategies for managers (Berman \& Evans, 2004). As a result, cruise managers increasingly feel the need to understand cruise passengers' perceptions of value, satisfaction, trust, and loyalty. This study, like a majority of the literature, adopts behavioral intentions as the measurement of loyalty (Ryu, Han, \& Kim, 2008).

Moreover, numerous earlier studies of cross-national differences in consumer behavior in different consumption sectors have verified that cultural differences have a strong influence on consumers, to the extent that the same product or service may be perceived differently according to the culture of origin and determine individual behavior (Cunningham, Young, Lee, \& Ulaga, 2006). With respect to the service industry, numerous studies take as reference the country dimension to explain different aspects of consumer behavior (Reimann, Lünemann, \& Chase, 2008; Yuksel, Kilinc, \& Yuksel, 2006). Despite the importance to cruise lines of cross-national analysis, no studies in the literature examine the moderating effects of nationality on the construction of behavioral intentions and their antecedents among cruise line passengers.
To fill this gap in the existing literature, the present paper aims to (i) develop and test a behavioral intentions model among passengers of cruise lines, and (ii) verify the moderating effects exercised by the nationality of cruise passengers - (U.S.) Americans and Spaniards. The sample consisted of passengers of cruise lines that operate in the Mediterranean and use Barcelona as home port and port-of-call.

\section{LITERATURE REVIEW AND HYPOTHESES DEVELOPMENT}

When we try to explain a customer's behavioral intentions towards a provider, and the continuity of a long-term customer relationship, it is essential to identify the factors determining the consumer's attitude towards the provider. Perceived value and perceived relationship quality can help structuring a model of behavior, as well as clarifying the inner processes that lead a customer to maintain stable relationships with a provider in the long term. The perceived quality of the relationship between two parties is formed from a series of key components that reflect the overall nature of the relationship. This is a mega-construct composed of satisfaction, trust, and loyalty (Moliner, Sánchez, Rodríguez, \& Callarisa, 2007).

Oliver (1999) defines consumer loyalty as the highest level of consumer commitment, implying the transition from a favorable predisposition towards a product to a repeated purchase commitment. However, research into consumer behavior has continued to study loyalty from different theoretical approaches (Yoon \& Uysal, 2005), such as the behavioral approach, which measures the sequence or the probability of purchase by the consumer; the attitudinal approach, in which the consumer expresses his/her loyalty on the basis of a psychological commitment or of a declaration of preferences; and the composite approach, which is an integration of the first two. These contributions notwithstanding, some authors believe that investigating loyalty as behavioral loyalty, by measuring attitudes over a certain period of time to verify repetition of purchase, is beyond the reach of researchers and impractical in most cases (Oppermann, 2000), so composite loyalty is difficult to apply. Furthermore, behavioral loyalty (Oliver's action phase) is only the static result of a dynamic process that does not explain why and how consumers, and, in our case, the passengers on a cruise, are willing to recommend it to other potential consumers (Yoon \& Uysal, 2005). For this reason, many researchers have considered an adequate measurement for the evaluation of loyalty to be the conative part of loyalty, which has frequently been measured as behavioral intentions with items like the intention to repurchase 
(Ryu et al., 2008), willingness to recommend (Hung \& Petrick, 2012; Tian-Cole, Crompton, \& Wilson, 2002), and positive wordof-mouth (Han \& Ryu, 2012; Parola, Satta, Penco, \& Persico, 2014).

Trust is defined in consumer behavior studies as a consumer's expectation that a supplier of products or provider of services will not behave opportunistically and will not take advantage of the consumer's situation of dependence and vulnerability (Rousseau, Sitkin, Burt, \& Camerer, 1998), presupposing a behavior that is trustworthy (Kumar, Scheer, \& Steenkamp, 1995). In general, reliability, fulfillment, credibility, honesty/integrity, competence, and benevolence are considered to be characteristics of trust (Kantsperger \& Kunz, 2010). Reliability means that what is agreed is always fulfilled (Delgado-Ballester, 2004). Fulfillment refers to the keeping of promises and is an indicator of reliability (Anderson \& Weitz, 1989). Credibility is based on the consumer's conviction that the provider has the necessary knowledge to perform the service (Kumar, Scheer, \& Steenkamp, 1995). Honesty/integrity means that the firm is known for always telling the truth and responding according to solid principles (Moliner et al., 2007). Competence refers to the capacity to make promises based on the organization's knowledge, experience, and skills (Sirdeshmukh, Singh, \& Sabol, 2002). And, finally, benevolence, meaning that the company is concerned for the customer's interests (Xie \& Peng, 2009). Most studies synthesize and integrate the characteristics of trust in two dimensions: honesty/credibility and benevolence (Kantsperger \& Kuntz, 2010). The literature has proved the relationship between trust and behavioral intentions in the cruise context (Forgas-Coll, Palau-Saumell, Sánchez-García, \& Caplliure-Giner, 2014). For this reason, it is hypothesized that:

$\mathrm{H}_{1}$ A cruise passenger's trust directly and positively influences his/her behavioral intentions towards a cruise line.

Most studies of consumer satisfaction have used models based on different theories, such as norm theory (Cadotte, Woodruff, \& Jenkins, 1987) in which agreement or disagreement with the norms will produce satisfaction or dissatisfaction; perceived performance theory (Tse \& Wilton, 1988) in which the consumer's satisfaction or dissatisfaction are based on the actual results and not on the initial expectations; equity theory (Fisk \& Young, 1985) in which the difference between the costs paid and the benefits expected are the determining factor in producing satisfaction or dissatisfaction (Heskett, Sasser, \& Schlesinger, 1997); and expectation/disconfirmation theory (Oliver, 1997). The latter is the dominant theory in the study of consumer satisfaction, defining satisfaction as a consumer's evaluation of whether the fulfillment of expectations has been pleasant or unpleasant.

Earlier research identified two types of satisfaction in consumer behavior, i.e., transaction-specific and overall satisfaction (Bitner \& Hubbert, 1994). Transaction-specific satisfaction is defined as the satisfaction with a specific service encounter (Bitner \& Hubbert, 1994). Overall satisfaction has been defined as the overall evaluation of the performance offered by a supplier up to a certain date Johnson \& Fornell, 1991). The overall satisfaction perspective is adopted in this study because a tourist's satisfaction is not limited to a specific product or service, but comprises an overall evaluation of his/her consumption experience (Johnson, Anderson, \& Fornell, 1995). The literature has proved the relationship between satisfaction and behavioral intentions (Chang \& Polonsky, 2012), and also in the cruise industry (Juan \& Chen, 2012). Previous studies have also found that satisfaction is an antecedent of trust (Santos \& Porto, 2014; Jani \& Han, 2011). So, based on these relationships, it is hypothesized that:

$\mathrm{H}_{2}$ A cruise passenger's satisfaction directly and positively influences his/her behavioral intentions towards a cruise line.

$\mathrm{H}_{3}$ A cruise passenger's satisfaction directly and positively influences his/her trust in a cruise line.

The operationalization of perceived value is an additive function that recognizes the integrated nature of benefits and sacrifices (DeSarbo, Jedidi, \& Sinha, 2001; Grewal, Monroe, \& Krishnan, 1998) with a multidimensional perspective, using multiple-item scales for better measurement. Sweeney and Soutar (2001) developed a scale with functional value, emotional value, and social value dimensions (PERVAL). Later, Sánchez, Callarisa, Rodríguez, and Moliner (2006) developed another scale in which they identified six dimensions: facilities, professionalism of the contact personnel, functional value of the product or service, price, emotional, and social value (GLOVAL). To these dimensions is added another one, i.e., non-monetary costs, associated with the consumer's effort, time, and risk in the purchase and consumption of a product or service (Cronin, Brady, \& Hult, 2000), validated by Forgas-Coll, Palau-Saumell, Sánchez-García, and CallarisaFiol (2012). In the context of cruises, Petrick (2002) developed the SERV-PERVAL scale in which he identified five dimensions: behavioral price, monetary price, emotional response, quality, and reputation. Later, the same author developed a model of cruise-passenger loyalty which considered only the service quality dimension of the SERV-PERVAL scale (Li \& Petrick, 2010), focused on the reliability of the quality of service.

The literature has also developed models of causal relationships of perceived value - as a multidimensional variable - with other constructs such as satisfaction, trust, and loyalty, and has found that the perceived value hypotheses could be only partially confirmed (Moliner et al., 2007). Other authors have 
preferred to operationalize perceived value by means of direct relationships between the dimensions of perceived value and other constructs (Fandos, Sánchez, \& Moliner, 2009; Gallarza \& Gil, 2006; Petrick, 2004). Following this last tendency, this study hypothesizes each of the dimensions of perceived value with other constructs supported by the literature that will be developed below. Thus, we have considered dimensions such as service quality, sacrifices (price and non-monetary costs), emotional value, and social value.

Service quality refers to the evaluation of the attributes of a service (Baker \& Crompton, 2000) and is defined as the difference between the expectations created by the consumers of the service and the performance or yield that they have obtained (Parasuraman, Zeithaml, \& Berry, 1988). Service quality is considered an antecedent of satisfaction, as well as having an influence on trust (Doney \& Canon, 1997), and on behavioral intentions (Baker \& Crompton, 2000; Li \& Petrick, 2010). In consequence, the followings hypotheses are proposed:

$\mathrm{H}_{4}$ The service quality perceived by a cruise passenger directly and positively influences his/her satisfaction with a cruise line.

$\mathrm{H}_{5}$ The service quality perceived by a cruise passenger directly and positively influences his/her trust in a cruise line.

$\mathrm{H}_{6}$ The service quality perceived by a cruise passenger directly and positively influences his/her behavioral intentions towards a cruise line.

Other dimensions refer to the sacrifices made by a consumer when purchasing a product or service. These sacrifices are the monetary costs of, or prices paid for, the products or services received, and non-monetary costs. Earlier studies have found a positive and direct relationship between favorable perceptions of price and satisfaction (Varki \& Colgate, 2001) and between perceived price and behavioral intentions (Zielke, 2010). Based on the empirical studies in different contexts, it is hypothesized that:

$\mathrm{H}_{7}$ The price perceived by a cruise passenger directly and positively influences his/her overall satisfaction with a cruise line.

$\mathrm{H}_{8}$ The price perceived by a cruise passenger directly and positively influences his/her behavioral intentions towards a cruise line.

The non-monetary costs are associated with the consumer's effort, time, and risk (Cronin et al., 2000). The relationship between non-monetary costs and other consumer behavior constructs has received little attention in the literature. Nevertheless, Forgas,
Moliner, Sánchez, and Palau (2010) found a direct and positive relationship between low levels of non-monetary costs and trust among airline customers. Based on this previous literature it is hypothesized that:

$\mathrm{H}_{9}$ The level of non-monetary costs perceived by a cruise passenger directly and positively influences his/her trust in a cruise line.

The emotions aroused by a service are associated with the most hedonic part of the consumption, such as happiness, amusement, enjoyment, fear, anger, envy, anxiety, or pride (Havlena \& Holbrook, 1986), which in cruises translate into intangible benefits of a symbolic, emotional, and hedonic nature (Kwortnik, 2008). Furthermore, emotions have a strong influence on satisfaction (Williams \& Soutar, 2009). Therefore, the following hypothesis is proposed:

$\mathrm{H}_{10}$ The emotional value perceived by a cruise passenger directly and positively influences his/her satisfaction with a cruise line.

Cruise programs encourage social participation and collective learning through games, competitions, and shared pastimes (Kwortnik, 2008). Earlier studies have shown that cruise passengers have a need to obtain social recognition (Hung \& Petrick, 2011) and also that social value influences cruising intentions (Forgas-Coll, Palau-Saumell, Sánchez-García, \& Caplliure-Giner, 2014). Hence:

$H_{11}$ The social value perceived by a cruise passenger directly and positively influences his/her behavioral intentions towards a cruise line.

\section{Cross-national moderating effects}

The globalization and internationalization of markets implies new processes of identity formation, cultural hybridization, and glocalization (Gould \& Grein, 2009). This process has aroused researchers' interest in analyzing cross-national effects on consumer behavior (Chan, Yim, \& Lam, 2010).

Numerous models of cultural dimensions exist. Those of Hofstede and Schwartz are the conceptual frameworks most cited, but the use of Schwartz's model has been limited and the results do not differ from those obtained with Hofstede's model (Drogendijk \& Slangen, 2006). Hofstede's model is the one most used in business and marketing studies (Tipton, 2009) and is based on comparisons and cultural distances between countries (Matos \& Leis, 2013; Stolz, Molina, Ramírez, \& Mohr, 2013). It has been criticized for its methodological development (Kirkman, Lowe, \& Gibson, 2006), because the consumer's behavior does not always correspond to the differences 
between countries expressed by Hofstede, or because nation cannot be equated with culture (McSweeney, 2002), but it is the model that has been most used to identify the cultural differences between countries (Soares, Farhangmehr, \& Shoham, 2007) and that has most influenced cross-cultural management.

Hofstede and Hofstede (2005) found among the individuals that they studied common cultural elements that could not be generalized at the individual level, since individuals could have different learning processes (Blodgett, Bakir, \& Rose, 2008), but could be generalized at country level, thus answering the critics since he states that the only units available for comparative evaluations are those corresponding to the nation-states (Hofstede, 2001). The latter developed a multidimensional model of collective identity with five dimensions, determining a score for each dimension and country. Individualism/collectivism and uncertainty avoidance dimensions were considered for the analysis, because Spain and the United States of America are two countries with opposite scores on these Hofstede dimensions. Spain is more collectivistic and shows high uncertainty avoidance; the United States of America has an opposite profile. Individualism explains the dialectical relationship between individuals and groups, and signifies that individualistic people are more concerned with themselves and their family circle than with the collective.

With respect to individualism/collectivism, moderator effects have been identified between satisfaction and loyalty (Forgas-Coll et al., 2012; Liu, Furrer, \& Sudharshan, 2001) and between attitude and intention (Kacen \& Lee, 2002). Moderator effects of uncertainty avoidance have been identified in repurchase intentions (Wong, 2004), and in relationships between perceived service quality and satisfaction (Reimann et al., 2008). In fact, the literature posits that collectivistic cultures, which have greater aversion to risk, act in the manner that socially is considered most appropriate, so they present a weaker relationship than individualistic cultures between attitude and intention, and between attitude and behavior (Kacen \& Lee, 2002). Based on the exposition of prior literature, the moderating effects are expected. Thus the following hypothesis is proposed:

$\mathrm{H}_{12}$ National Culture moderates the causal relationships posited in the structural model.

After reviewing the literature and detailing the relationships between constructs, we propose the model with the moderator effects of nationality shown in Figure. 1

\section{Figure 1. The proposed structural model}

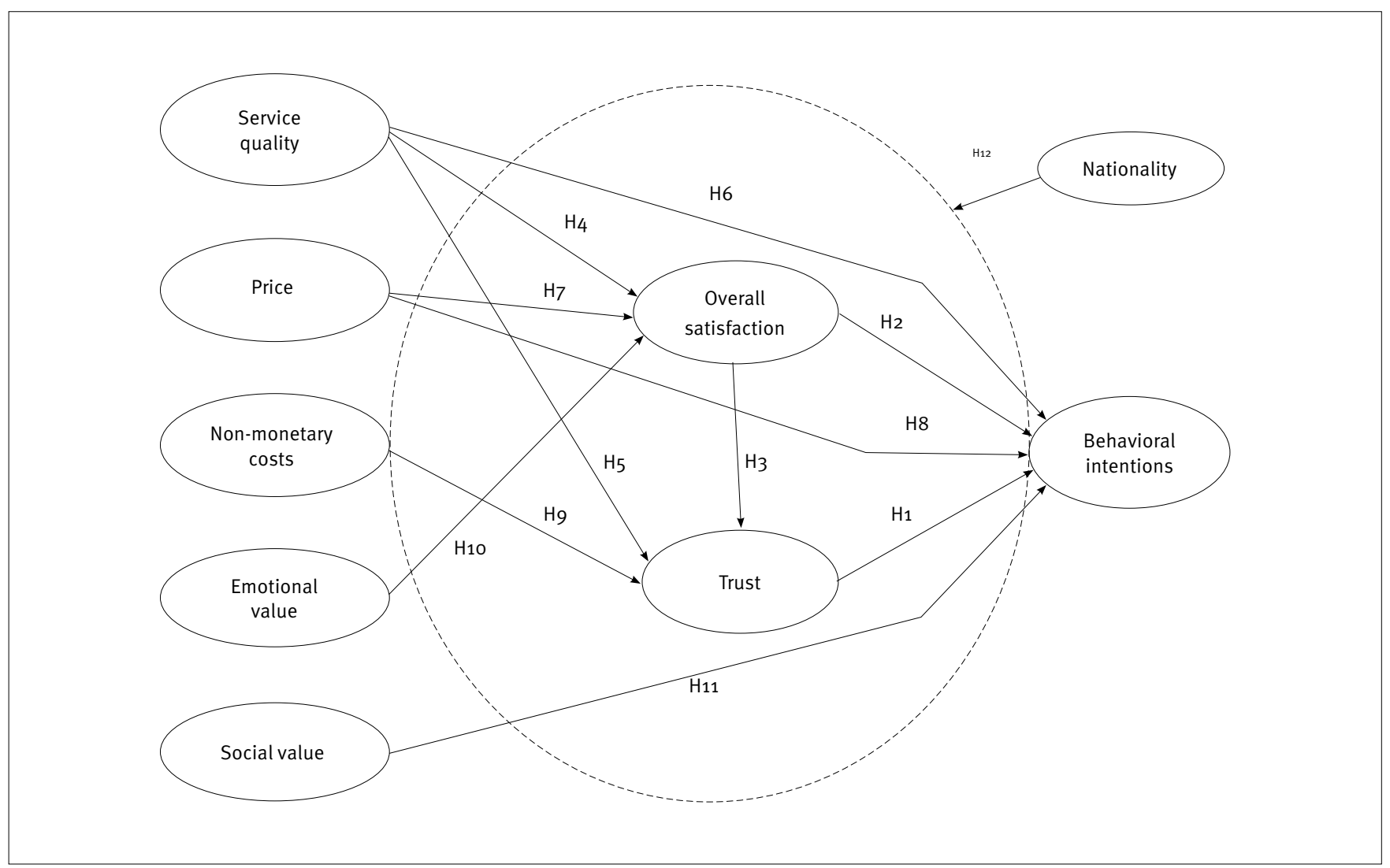




\section{METHODOLOGY}

The survey questionnaire was developed on the basis of the literature review with pre-existing items for each construct. The questionnaire consisted of five sections: perceived value, customer satisfaction, trust, behavioral intentions, and demographic information. Perceived value was operationalized with five dimensions: service quality, price perception, nonmonetary costs, emotional value, and social value. Four items of service quality were adapted from the work of Sánchez et al. (2006). Price was measured by three items adapted from Zielke (2010) and Oh (2000). Non-monetary costs were measured by two items from Cronin et al. (2000) and one from Forgas et al. (2010). Three items for emotional value and three items for social value were derived from Sweeney and Soutar (2001). Satisfaction was measured with three items employed by Lee, Yoon, and Lee (2007). Trust was measured with one item of benevolence and two items of credibility based on Kantsperger and Kuntz (2010). Three items from Tian-Cole et al. (2002) and Li and Petrick (2008) were used to measure behavioral intentions.

The items were reviewed by means of qualitative interviews with travel agency professionals with experience in the sale of cruises. The qualitative work confirmed the selection of items with the necessary adaptations to the context of cruise tourism, except in the item The time required to use this cruise trip is reasonable (Cronin et al., 2000), which, after the qualitative interviews, became The time required to buy this cruise trip is reasonable. Furthermore, to test the items, a pre-test with 50 personal interviews was conducted during May 2011. All this allowed the wording of some of the items of the questionnaire to be improved. The items of the questionnaire were valued by means of a 5 -point Likert scale where $1=$ Totally Disagree and $5=$ Totally Agree.

A total of 1,010 personal interviews were conducted during the months of May to July 2011, of which 42 questionnaires were rejected because they were incomplete, 968 interviews finally being accepted. The interviews were conducted with (U.S.) American cruise passengers, born and resident in the United States of America, and Spanish cruise passengers, born and resident in Spain, who sailed on different cruise lines and disembarked in the Port of Barcelona. The surveys were conducted in American English with the Americans and in Spanish with the Spaniards. The information was gathered on the basis of a convenience sampling strategy. Finally, 497 interviewees were from the United States of America (50.3\%) and 471 were from Spain (49.7\%). With regard to the sample profile, $53 \%$ of the respondents were men $\mathbf{5 2 . 1 \%}$ Americans, 55.8\% Spaniards). Twelve percent were between eighteen and 34 years old (10.5\% Americans, 13.5\% Spaniards), $22 \%$ between 35 and 44 (23.3\% Americans, 20.6\% Spaniards), $25 \%$ between 45 and 54 (23.1\% Americans, 26.9\%, Spaniards 26.9\%), 28\% between 55 and 64 (30.9\% Americans, 24.8\% Spaniards), and $13 \%$ were 65 and over (11.8\% Americans, $14.2 \%$ Spaniards). With regard to educational level, $5 \%$ had elementary education ( $4 \%$ Americans, 6\% Spaniards), 31\% a high school qualification (29\% Americans, 33\% Spaniards), and 64\% a higher education degree (67\% Americans, 61\% Spaniards).

The study of data used structural equation models by means of a multi-group analysis. The models were estimated from the matrices of variances and covariances by the maximum likelihood procedure, using EQS 6.1 statistical software (Bentler, 1995). First, a study of the dimensionality, reliability, and validity of the scale used was conducted to ensure that we were measuring the constructs it was intended to measure. The invariance of the instrument of measurement was then verified, in order to be able to compare the regression coefficients of each of the two samples (moderator effect-hypothesis 12). Prior to this comparison, the causal relationships for the whole sample were determined in order to test hypotheses 1 to 11.

\section{RESULTS}

In the first phase of the analysis, the study was focused on the psychometrical properties of the scales of measurement of the variables for the whole sample. As can be observed in Table 1, the probability associated with chi-squared reaches a value higher than 0.05 , indicating an overall good fit of the scales (Jöreskog \& Sörbom, 1996). The convergent validity is demonstrated in two ways. First because the factor loadings are significant and greater than 0.5 (Bagozzi \& Yi, 1988; Hair, Black, Babin, Anderson, \& Tatham, 2006); and second because the average variance extracted (AVE) for each of the factors is higher than 0.5 (Fornell \& Larcker, 1981). The reliability of the scale is demonstrated because the composite reliability indices of each of the dimensions obtained are higher than 0.6 (Bagozzi $\& Y i, 1988)$.

Table 2 shows the discriminant validity of the constructs considered, evaluated by means of average variance extractedAVE (Fornell \& Larcker, 1981). For this, a construct must share more variance with its indicators than with other constructs of the model shown when the square root of the AVE between each pair of factors is higher than the estimated correlation between those factors. This does occur here, thus ratifying its discriminant validity. 
Table 1. Analysis of the dimensionality, reliability and validity of the scales of measurement (Fully standardized solution)

\begin{tabular}{|c|c|c|}
\hline Items & $\begin{array}{l}\text { Factor } \\
\text { loading }\end{array}$ & t-Value \\
\hline The installations were spacious, modern and clean & 0.60 & $14 \cdot 75$ \\
\hline The staff knew their job well & 0.78 & 22.45 \\
\hline The quality of on-board services was maintained throughout & 0.63 & 19.71 \\
\hline \multicolumn{3}{|l|}{ Price $(C R=0.79 ; A V E=0.62)$} \\
\hline The price is reasonable & 0.76 & 26.30 \\
\hline \multicolumn{3}{|l|}{ Non-monetary costs $(C R=0.88 ; A V E=0.75)$} \\
\hline The time and effort of getting to the port of embarkation was not a problem & 0.84 & 29.99 \\
\hline The effort that I must make to receive the services offered on-board is reasonable & 0.93 & 39.50 \\
\hline The time required to buy this cruise trip is reasonable & 0.76 & 29.16 \\
\hline \multicolumn{3}{|l|}{ Emotional value $(C R=0.83 ; A V E=0.67)$} \\
\hline The cruise was pleasurable & 0.78 & 22.20 \\
\hline Cruising made me feel better & 0.81 & 22.62 \\
\hline \multicolumn{3}{|l|}{ Satisfaction $(C R=0.90 ;$ AVE $=0.78)$} \\
\hline Satisfied with the cruise trip when compared with expectations & 0.86 & 24.70 \\
\hline Satisfied with the cruise trip when considering time and effort & 0.85 & 26.65 \\
\hline Overall satisfaction with the cruise trip & 0.90 & 25.16 \\
\hline \multicolumn{3}{|l|}{ Trust in the company $(C R=0.80 ; A V E=0.64)$} \\
\hline This cruise line is very thoughtful about my on-board well-being & 0.82 & 29.32 \\
\hline I think this cruise line is trustworthy & 0.84 & 26.50 \\
\hline This cruise line was able to satisfy my on-board needs & 0.61 & 26.53 \\
\hline \multicolumn{3}{|l|}{ Behavioral intentions $(C R=0.91 ;$ AVE $=0.79)$} \\
\hline I will say positive things about the cruise to other people & 0.85 & 27.30 \\
\hline I will encourage friends and relatives to go on this cruise & 0.88 & 29.56 \\
\hline I consider this cruise line my first cruising choice & 0.90 & 29.65 \\
\hline
\end{tabular}

Note. $C R=$ Composite reliability; $A V E=$ Average Variance Extracted. Fit of the model: Chi-squared $=265.6566 ; \mathrm{df}=243 ; \mathrm{P}=0.152108 ; \mathrm{RMSEA}=0.045 ; \mathrm{NNFI}=0.981 ; \mathrm{CFI}=0.988$. 
Table 2. Discriminant validity of the scales associated with the model

\begin{tabular}{l|c|c|c|c|c|c|c|c}
\hline & $\mathbf{1}$ & $\mathbf{2}$ & $\mathbf{3}$ & $\mathbf{4}$ & $\mathbf{5}$ & $\mathbf{6}$ & $\mathbf{7}$ & $\mathbf{8}$ \\
\hline 1. Service quality & 0.76 & & & & & & \\
\hline 2. Price & 0.39 & 0.79 & & & & & \\
\hline 3. Non-monetary costs & 0.65 & 0.46 & 0.86 & & & & & \\
\hline 4. Emotional value & 0.30 & 0.32 & 0.35 & 0.82 & & & & \\
\hline 5. Social value & 0.58 & 0.43 & 0.58 & 0.33 & 0.72 & & \\
\hline 6. Satisfaction & 0.55 & 0.46 & 0.49 & 0.29 & 0.53 & 0.88 & \\
\hline 7. Trust & 0.53 & 0.45 & 0.52 & 0.37 & 0.58 & 0.57 & 0.80 & \\
\hline 8. Behavioral intentions & 0.53 & 0.45 & 0.52 & 0.37 & 0.58 & 0.57 & 0.88 & 0.89 \\
\hline
\end{tabular}

Note. Below the diagonal: estimated correlation between the factors. Diagonal: square root of AVE.

After that, the focus was on the development of the invariance of the instrument of measurement. This analysis is prior to the verification of the differences between the groups considered in the parameters that are common to the study variables (Byrne, 2006; Hair et al., 2006). The first step considers the model individually for each of the samples. As we observe in Table 3, the model fits well, separately, in the two samples, i.e., Americans $\left(x^{2}=640.497 ; d f=243\right)$ and Spaniards $\left(x^{2}=654.262\right.$; $\mathrm{df}=243)$. The second step estimates the model simultaneously in both samples, to verify that the number of factors is the same, i.e. that they have the same form, and again the model fits adequately $\left(x^{2}=1294.759 ; d f=486\right)$. The third and last step refers to the equality of the factor loadings in the two groups (metrical invariance). When this restriction is introduced into the model we observe that the model fit is not significantly worse than that of the previous step, as deduced from the comparison between the $x^{2}$ of steps 2 and $3\left(\Delta x^{2}=35.726 ; \Delta d f=25 ; p=0,075>0,05\right)$, so the invariance of the factor loadings is ratified.

\section{Table 3. Invariance measurement}

\begin{tabular}{l|l|l|l|l|l|l|l|l|l|l|l}
\hline & $\mathrm{x}^{2}$ & $\mathrm{df}$ & $\Delta \mathrm{x}^{2}$ & $\Delta \mathrm{df}$ & $\mathrm{p}$ & $\mathrm{RMSEA}(90 \% \mathrm{Cl})$ & SRMR & CFI & NNFI \\
\hline \multicolumn{7}{l}{ Individual groups: } \\
\hline Americans & 640.497 & 243 & & & & $0.029(0.021-0.036)$ & 0.045 & 0.987 & 0.983 \\
\hline Spaniards & 654.262 & 243 & & & & $0.044(0.038-0.050)$ & 0.056 & 0.981 & 0.978 \\
\hline Measurement of Invariance: & 1294.759 & 486 & & & & $0.057(0.053-0.071)$ & 0.050 & 0.975 & 0.970 \\
\hline Simultaneous model & 1330.485 & 511 & 35.726 & 25 & 0.075 & $0.059(0.055-0.062)$ & 0.063 & 0.969 & 0.963 \\
\hline Model with restricted factor loadings & & & & &
\end{tabular}

\section{Causal relationships and moderator effects}

To test hypotheses 1 to 11 , the causal relationships for the total sample were analyzed (Table 4). This is adequate, because the probability of the chi-squared is higher than 0.05 (0.21109), CFI (0.996) is close to unity and RMSEA is close to zero (0.076), so the model estimated provided a good fit to the data. Additionally, in the model, the variance in satisfaction $\left(R^{2}=0.679\right)$ is explained by service quality, price, and emotional value; the variance in trust $\left(R^{2}=0.782\right)$ is explained by service quality, non-monetary costs, and satisfaction; and the variance in behavioral intentions $\left(R^{2}=\right.$ 0.713 ) can be attributed to satisfaction, trust, and social value, indicating that the model of the current study could well predict and explain customer behavioral intentions.
Summarizing the result of the hypotheses, the analysis shows that nine of the hypotheses put forward are supported and two are rejected for the sample as a whole. Table 4 shows a direct and positive relationship between service quality and satisfaction, service quality and trust, price and satisfaction, nonmonetary costs and trust, emotional value and satisfaction, social value and behavioral intentions, satisfaction and behavioral intentions, satisfaction and trust, and trust and behavioral intentions, providing support for hypotheses 1, 2, 3, 4, 5, 7, 9, 10 , and 11 . On the other hand, no direct relationships were found between service quality and behavioral intentions, or between price and behavioral intentions. So, hypotheses 6 and 8 are not supported. 
Table 4. Structural model: Relationships obtained

\begin{tabular}{|c|c|c|c|}
\hline Path & Parameter & $\mathrm{t}$ & Results \\
\hline Price .... Satisfaction & 0.18 & 4.27 & Supported \\
\hline Service quality $\ldots . . . *$ Trust & 0.52 & 27.72 & Supported \\
\hline Non-monetary costs $\cdots \cdot$ Trust & 0.05 & 2.13 & Supported \\
\hline Service quality $\ldots . \cdots$ Behavioral intentions & 0.00 & 0.01 & Rejected \\
\hline Price $\ldots . .>$ Behavioral intentions & 0.04 & 1.14 & Rejected \\
\hline Social value $\ldots . .$. Behavioral intentions & 0.14 & 4.62 & Supported \\
\hline Satisfaction .... Behavioral intentions & 0.45 & 8.18 & Supported \\
\hline
\end{tabular}

Note. Fit of the model: Chi-squared $=280.1113 ; \mathrm{df}=260 ; \mathrm{P}=0.21109 ; \mathrm{RMSEA}=0.076 ; \mathrm{CFI}=0.996 ; \mathrm{NNFI}=0.996$.

Next, the existence of significant differences in the causal relationships is estimated, in order to analyze the moderating effect exercised by the different nationalities. The restrictions that permit calculating these significant differences between the parameters estimated, through comparison of the $x^{2}$ of the restricted structural model with the $x^{2}$ of the unrestricted structural model, are added as shown in Table 5. All this allows $\mathrm{H}_{12}$ to be tested.

The analysis carried out to establish the causal relationships between the variables being studied is adequate, because the probability of the chi-squared is higher than 0.05 (0.10223429), CFI (0.996) is close to unity, and RMSEA is close to zero (0.078).

Nationality was found to partially moderate the model $\left(H_{12}\right)$. Table 5 and Figure 2 show the significant differences between Americans and Spaniards in some of the causal relationships considered in the model. The causal relationships are more significant in the sample of Spanish cruise passengers than in that of Americans between emotional value and satisfaction ( 0.70 and $0.47, \Delta x^{2}=8.29 ; p=0.01<0.05$ ), and between trust and behavioral intentions ( 0.49 and $0.27 ; \Delta x^{2}=$ $5.20 ; p=0.02<0.05)$. On the other hand, stronger relationships were found in the sample of Americans than in that of Spaniards between service quality and satisfaction ( 0.53 and $0.30, \Delta \mathrm{x}^{2}=$ 4.76; $p=0.03(0.05)$ and between service quality and behavioral intentions ( 0.19 and $0.11, \Delta x^{2}=4.79 ; p=0.03<0.05$ ). In this case, these last relationships are not significant in the sample of Spaniards.

\section{Table 5. Relationships obtained moderated by nationality}

\begin{tabular}{|c|c|c|c|c|c|c|c|}
\hline Path & $\begin{array}{c}\text { (U.S.) Americans } \\
\text { Parameter }\end{array}$ & $\mathrm{t}$ & $\begin{array}{l}\text { Spaniards } \\
\text { Parameter }\end{array}$ & $\mathrm{t}$ & $\Delta \mathrm{x}^{2}$ & $\mathrm{p}$ & Results \\
\hline Service quality $\cdots$... Satisfaction & 0.53 & 10.46 & 0.30 & 5.79 & 4.76 & 0.03 & Supported \\
\hline Price... S Satisfaction & 0.18 & 3.06 & 0.17 & 3.00 & 0.06 & 0.80 & Rejected \\
\hline Emotional value.. .3 Satisfaction & 0.47 & 9.76 & 0.70 & 13.99 & 8.29 & 0.01 & Supported \\
\hline Non-monetary costs $\ldots .$. Trust & 0.05 & 1.65 & 0.04 & 1.33 & 0.05 & 0.81 & Rejected \\
\hline Satisfaction $\cdots . .$. Trust & 0.47 & 10.02 & 0.50 & 10.81 & 1.33 & 0.25 & Rejected \\
\hline Service quality $\cdots \cdot 3$ Behavioral intentions & 0.19 & 2.80 & 0.11 & 1.15 & 4.79 & 0.03 & Supported \\
\hline Price .... Behavioral intentions & 0.01 & 0.18 & 0.09 & 1.78 & 0.91 & 0.34 & Rejected \\
\hline Trust $\ldots$... Behavioral intentions & 0.27 & 2.81 & 0.49 & 3.46 & 5.20 & 0.02 & Supported \\
\hline
\end{tabular}

Note. Fit of the model: Chi-squared $=583.1233 ; \mathrm{df}=541 ; \mathrm{P}=0.102234296 ; \mathrm{RMSEA}=0.078 ; \mathrm{CFI}=0.996 ; \mathrm{NNFI}=0.995$. Simultaneously latent variables test: $\Delta \mathrm{x}^{2}=23.317$; $\Delta d f=11 ; p=0.0159<0.0$ 
Figure 2. Estimated results of the model by nationality. Parameters of Americans above, Parameters of Spaniards below

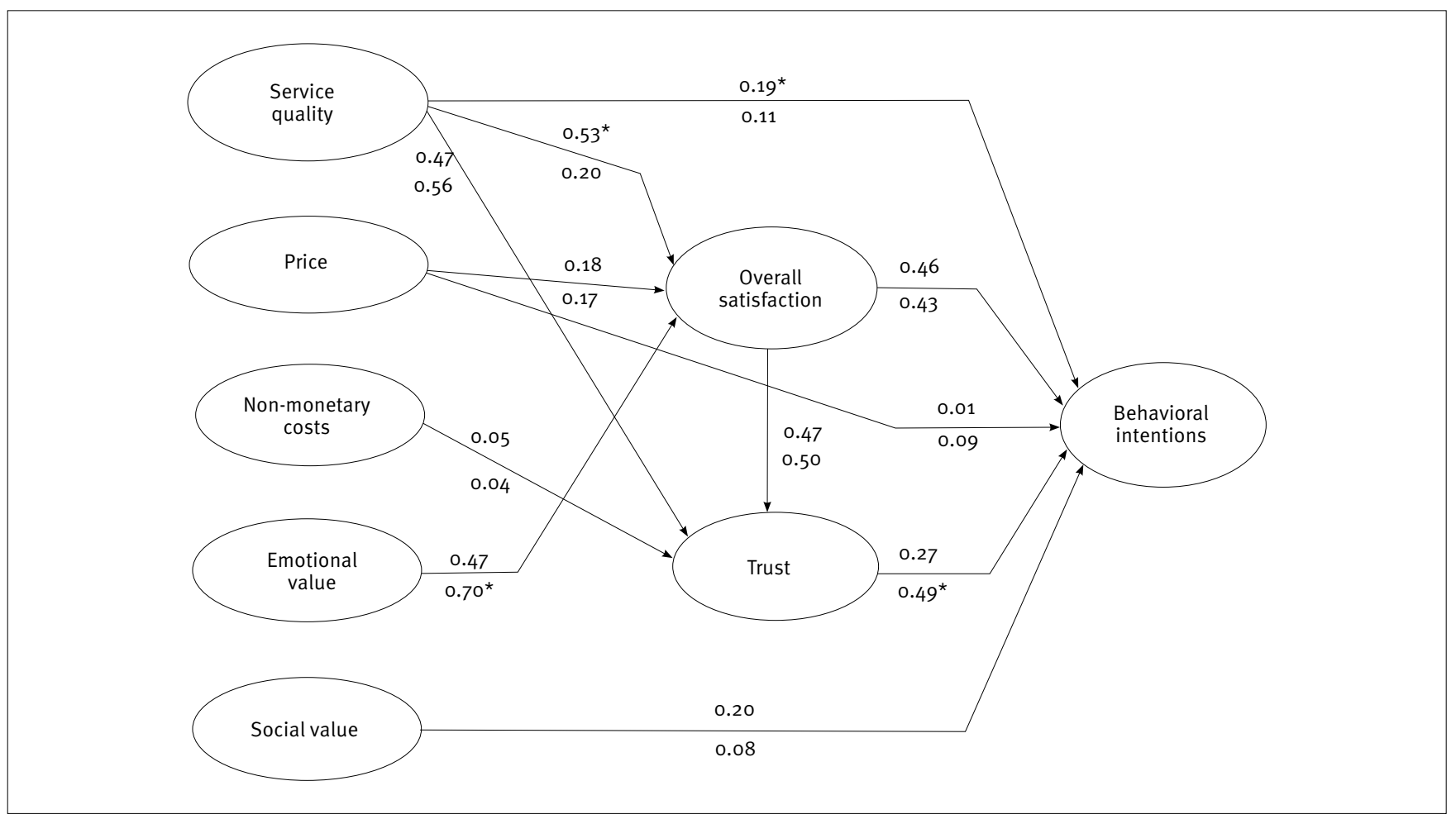

* When there are significant differences ( $\mathrm{p}<0.05)$, the higher value is marked. Fit of the model: Chi-squared =583.1233, $\mathrm{df}=541, \mathrm{P}=0.102234296 ; \mathrm{RMSEA}=0.078 ; \mathrm{CFI}=$ $0.996 ; \mathrm{NNFI}=0.995$.

\section{DISCUSSION AND CONCLUSIONS}

This research aimed to demonstrate that perceived value, satisfaction, and trust were important predictors of passengers' behavioral intentions towards the cruise line. From these results, it is believed that the behavioral intentions model outlined in the conceptual framework is corroborated.

However, the main contribution of this study is that it analyzes the effects of nationality on the formation of passengers' behavioral intentions towards a cruise line. The results show significant differences between Americans and Spaniards in four causal relationships. The analysis is interpreted on the basis of two of the dimensions of Hofstede and Hofstede (2005) in which the two groups are most widely separated: individualism/ collectivism and uncertainty avoidance.

The results demonstrate that the strongest links between emotional value and satisfaction, and trust and behavioral intentions occur in the sample of Spaniards. This finding can be interpreted on the basis of the idea that more individualistic cultures, like the American, which have low uncertainty avoidance, tend to show emotions less and do not separate them from rational decisions, while more collectivistic cultures do (Trompenaars, 1997). Also, collectivistic cultures base their trust on relationships with first-hand knowledge, while an individualistic culture is much more likely to trust others until they are given some reason not to trust (Jarvenpaa, Tractinsky, \& Saarinen, 1999). Consequently, collectivistic cultures, which have high uncertainty avoidance, try to mitigate risk by building trust through the experience, the benevolence, and the credibility of whoever is performing the service (Doney, Cannon, \& Mullen, 1998), so once the trust is built it has a greater effect on behavioral intentions. Hence, cruise lines must create emotional, enjoyable, and entertaining experiences not perceived as boring and routine in order to increase positive emotions. For individualistic cultures, with higher levels of subjective well-being perception than collectivistic cultures, activities should be prepared to avoid queuing, crowding, baggage handling, or transfers during the cruise, which are issues perceived as unsatisfactory. Cruise lines need to create more emotional experiences in order to increase the feeling of wellbeing of American passengers. The feeling of well-being aboard could influence the belief that the cruise company is able to satisfy the needs and is trustworthy.

On the other hand, in the American sample the relationships between service quality and satisfaction is significantly stronger than in the sample of Spaniards and, also the relationship between service quality and behavioral intentions is significant 
in the American sample while in the Spanish sample it is not. These results are consistent with Kacen and Lee (2002), since the attitude-intention relationship is weaker in the collectivistic sample with high uncertainty avoidance. This difference is because highly individualistic cultures, which in turn have low uncertainty avoidance, are more demanding in the evaluation of service quality, so their satisfaction increases at high levels of service quality (Birgelen, Ruyter, Jong, \& Wetzels, 2002), and consequently also result in a favorable predisposition towards behavioral intentions. For this reason more collectivist cultures with high uncertainty avoidance, such as Spaniards, would require greater staff involvement in the on-board services. This involvement could be achieved by increasing interaction with the cruise passengers in those collective participation activities in which crew members' performance could improve customer satisfaction. Consequently, cruise lines should be investing in a specific training program for staff on- board to design activities and services taking into account the passenger's cultural differences.

As far as the sample as a whole is concerned, the study makes other contributions. The first is the incorporation of nonmonetary costs into a model of formation of behavioral intentions in the context of cruises. This study found a direct and positive relationship between low levels of non-monetary costs and trust, which confirms the findings of Forgas et al. (2010) in other context and is a contribution in the field of cruises. The second is the important role played by trust. As the results show, trust acts as a mediating variable between satisfaction and behavioral intentions, and between service quality and behavioral intentions, which confirms the findings of Moliner et al. (2007) and ForgasColl et al. (2014). Consequently, trust is shown to be a key factor in the formation of cruise passengers' behavioral intentions.

For cruise firms to continue to increase market share in Europe, considering the uncertainty of the current economic crisis, the managers of such cruise firms should bear in mind cultural differences in the behavior of cruise passengers. In sum, in order to create stable and lasting relationships with their customers, firms should pay attention to the differences between individualistic and collectivistic cultures and between cultures with low or high uncertainty avoidance. In view of the significant differences between the cruise passengers of the nationalities analyzed, there are some managerial implications. First, cruise companies could offer services that help to reduce these differences. Such is the case of the cognitive variables, which are considered by the cruise industry to be the most important strengths in the sale of cruise holidays (Cruise Lines International Association, 2012), on which firms can work. The cruise lines should adjust the service quality better to the needs of Spaniards, since in general, the services offered by cruise lines are highly focused on a North American public. In this sense, the CLIA figures for 2012 indicate that $69 \%$ of international passengers are American (USA and Canadian).

Another implication for cruise lines is that in order to improve the relationship between trust and behavioral intentions in more individualistic passengers, who make more rational decisions, like US Americans, continuous improvement of service quality is necessary. The development of plans for continued improvement of quality is especially important for cruise lines, to show that the company keeps its promises.

Finally, another implication is to pay attention to emotions as an antecedent of satisfaction. Companies have to continue working on emotional aspects in the on-board services of the cruise trip, particularly for cruise passengers from highly individualistic cultures, in order to achieve even more intense levels of emotion.

The main limitation of this study is that it only considers Americans and Spaniards in analyzing the moderator effects of nationality. Future investigations could consider including more nationalities and analyzing them separately, or dividing them among national groups with similar scores for individualism and/ or uncertainty avoidance.

\section{REFERENCES}

Anderson, E., \& Weitz, B. (1989). Determinants of continuity in conventional industrial channel dyads. Marketing Sciences, 8(4), 310-323. doi:10.1287/mksc.8.4.310

Bagozzi, R. P., \& Yi, T. (1988). On the evaluation of structural equation models. Journal of the Academy of Marketing Science, 16(1), 74-94. doi:10.1007/bfo2723327

Baker, D. A., \& Crompton, J. L. (2000). Quality, satisfaction and behavioral intentions. Annals of Tourism Research, 27(3), 785-804. doi:10.1016/S0160-7383(99)00108-5

Barcelona Tourism. (2011). Statistics of tourism. Retrieved from http:// professional.barcelonaturisme.com/files/8848-102-pdf_CAST/ Estadistiques-sintesis-2011.pdf

Bentler, P. M. (1995). EQS structural equations program manual. Encino: Multivariate Software Inc.

Berman, B., \& Evans, J. R. (2004). Retailing management (gth ed.). New York: Macmillan Publishing.

Birgelen, M., Ruyter, K., Jong, A., \& Wetzels, M. (2002). Customer evaluations of after-sales contact modes: An empirical analysis of national culture's consequences. International Journal of Research in Marketing, 19(1), 43-64. doi:10.1016/S0167-8116(02)00047-2

Bitner, M. J., \& Hubbert, A. R. (1994). Encounter satisfaction versus overall satisfaction versus quality. In R. T. Rust, \& R. L. Oliver (Eds.), Service quality: New directions in theory and practice (pp. 72-94). Thousand Oaks, CA: Sage. 
Blodgett, J. G., Bakir, A., \& Rose, G. M. (2008). A test of the validity of Hofstede's cultural framework. Journal of Consumer Marketing, 25(6), 339-349. doi:10.1108/07363760810902477

Byrne, B. M. (2006). Structural equation modelling with EQS: Basic concepts, applications and programming (2nd ed.). Mahwah: Lawrence Erlbaum Associates, Inc.

Cadotte, E. R., Woodruff, R. B., \& Jenkins, R. L. (1987). Expectations and norms in models of consumer satisfaction. Journal of Marketing Research, 24(3), 305-314. doi:10.2307/3151641

Chan, K. W., Yim, C. K., \& Lam, S. S. K. (2010). Is customer participation in value creation a double-edged sword? Evidence from professional financial services across cultures. Journal of Marketing, 74(3), 48-64. doi:10.1509/jmkg.74.3.48

Chang, Y-W., \& Polonsky, M. J. (2012). The influence of multiple types of service convenience on behavioral intentions: The mediating role of consumer satisfaction in a Taiwanese leisure setting. International Journal of Hospitality Management, 31(1), 107-118. doi:10.1016/j. ijhm.2011.05.003

Cronin, J., Brady, M., \& Hult, G. T. (2000). Assessing the effects of quality, value and customer satisfaction on consumer behavioral intentions in service environments. Journal of Retailing, 76(2), 193218. doi:10.1016/So022-4359(00)00028-2

Cruise Lines International Association. (2012). Industry update. Retrieved from http://www.cruising.org/sites/default/files/pressroom/2012CLIAIndustryUpdate.pdf

Cunningham, L. F., Young, C. E., Lee, M., \& Ulaga, W. (2006). Customer perceptions of service dimensions: Cross-cultural analysis and perspective. International Marketing Review, 23(2), 192-210. doi:10.1108/02651330610660083

Delgado-Ballester, E. (2004). Applicability of a brand trust scale across productcategories:Amultigroup invariance analysis. EuropeanJournal of Marketing, 38(5-6), 573-592. doi:10.1108/03090560410529222

DeSarbo, W. S., Jedidi, K., \& Sinha, I. (2001). Customer value analysis in a heterogeneous market. Strategic Management Journal, 22(9), 845857. doi:10.1002/smj.191

Doney, P. M., \& Cannon, J. P. (1997). An examination of the nature of trust in buyer-seller relationships. Journal of Marketing, 61(2), 35-51. doi:10.2307/1251829

Doney, P. M., Cannon, J. P., \& Mullen, M. R. (1998). Understanding the influence of national culture on the development of trust. Academy of Management Review, 23(3), 601-620.

Drogendijk, R., \& Slangen, A. (2006). Hofstede, Schwartz, or managerial perceptions? The effects of different cultural distance measures on establishment mode choices by multinational enterprises. International Business Review, 15(4), 361-380. doi:10.1016/j. ibusrev.2006.05.003

European Cruise Council. (2013). 2012/2013 Report. Making a real social and economic contribution to Europe's economy. Retrieved from http://www.europeancruisecouncil.com/content/ECC\%2 Report\%202012-13.pdf

Fandos, J. C., Sánchez, J., \& Moliner, M. A. (2009). Perceived value and customer loyalty in financial services. Services Industries Journal, 29(6), 775-789. doi:10.1080/02642060902749286

Fisk, R. P., \& Young, C. E. (1985). Disconfirmation of equity expectations: Effects on consumer satisfaction with services. In E. C. Hirschman, \& M. B. Holbrook (Eds.), Advances in consumer research (pp. 340-345). Provo, UT: Association for Consumer Research.
Forgas, S., Moliner, M. A., Sánchez, J. \& Palau, R. (2010). Antecedents of airline passenger loyalty: Low-cost versus traditional airlines. Journal of Air Transport Management, 16(4), 229-233. doi:10.1016/j. jairtraman.2010.01.001

Forgas-Coll, S., Palau-Saumell, R., Sánchez-García, J., \& Callarisa-Fiol, L. (2012). Urban destination loyalty drivers and cross-national moderator effects: The case of Barcelona. Tourism Management, 33(6), 1309-1320. doi:10.1016/j.tourman.2011.12.013

Forgas-Coll, S., Palau-Saumell, R., Sánchez-García, J., \& CaplliureGiner, E. M. (2014). The role of trust in cruise passenger behavioral intentions: The moderating effects of the cruise line brand. Management Decision, 52(8), 1346-1367. doi:10.1108/MD-09-20120674

Fornell, C., \& Larcker, D. F. (1981). Evaluating structural equations models with unobservable variables and measurement error. Journal of Marketing Research, 18(1), 39-50. doi:10.2307/3151312

Gallarza, M. G., \& Gil, I. (2006). Value dimensions, perceived value, satisfaction and loyalty: An investigation of university students' travel behavior. Tourism Management, 27(3), 437-452. doi:10.1016/j. tourman.2004.12.002

Gould, S. J., \& Grein, A. F. (2009). Think glocally, act glocally: A culturecentric comment on Leung, Bhagat, Buchan, Erez and Gibson (2005). Journal of International Business Study, 40(2), 237-254. doi:10.1057/ palgrave.jibs. 8400410

Grewal, D., Monroe, K. B., \& Krishnan, R. (1998). The effects of price comparison advertising on buyers' perceptions of acquisition value, transaction value and behavioral intentions. Journal of Marketing, 62(2), 46-59. doi:10.2307/1252160

Hair, J. F., Black, W. C., Babin, J. B., Anderson, R. E., \& Tatham, R. L. (2006). Multivariate data analysis (6th ed). Upper Saddle River: Pearson Education Inc.

Han, H., \& Ryu, K. (2012). Key factors driving customers' word-ofmouth intentions in full service restaurants: The moderating role of switching costs. Cornell Hospitality Quarterly, 53(2), 96-109. doi:10.1177/1938965511433599

Havlena, W. J., \& Holbrook, M. B. (1986). The varieties of consumption experience: Comparing two typologies of emotion in consumer behavior. Journal of Consumer Research, 13(3), 394-404.

Heskett, J. L., Sasser, W. E., \& Schlesinger, L. A. (1997). The service profit chain. New York: The Free Press.

Hofstede, G. (2001). Culture's consequences: Comparing values, behaviors, institutions and organizations across nations. London: Sage.

Hofstede, G., \& Hofstede, G. F. (2005). Culture and organizations: Software of the mind (2nd ed.). New York: McGraw Hill.

Hung, K., \& Petrick, J. F. (2011). The role of self- and functional congruity in cruising intentions. Journal of Travel Research, 50(1), 100-112. doi:10.1177/0047287509355321

Hung, K. \& Petrick, F. P. (2012). Testing the effects of congruity, travel constraints, and self-efficacy on travel intentions: An alternative decision-making model. Tourism Management, 33(4), 855-867. doi:10.1016/j.tourman.2011.09.007

Jani, D., \& Han, H. (2011). Investigation the key factors affecting behavioral intentions. Evidence from a full-service restaurant setting. International Journal of Contemporary Hospitality Management, 23(7), 1000-1018. Doi:10.1108/09596111111167579 
Jarvenpaa, S. L., Tractinsky, N., \& Saarinen, L. (1999). Consumer trust in an internet store: A cross-cultural validation. Journal of ComputerMediated Communication Retrieved from http://onlinelibrary.wiley. com/journal/10.1111/(ISSN)1083-6101

Johnson, M. D., \& Fornell, C. (1991). A framework for comparing customer satisfaction across individuals and product categories. Journal of Economic Psychology, 12(2), 267-286. doi:10.1016/01674870(91)90016-m

Johnson, M. D., Anderson, E. W., \& Fornell, C. (1995). Rational and adaptive performance expectations in a customer satisfaction framework. Journal of Consumer Research, 21(4), 695-707.

Jöreskog, K. G., \& Sörbom, D. (1996). LISREL 8: User’s reference guide. Chicago: Scientific Software.

Juan, P-J., \& Chen, H-M. (2012). Taiwanese cruise tourist behavior during different phases of experience. International Journal of Tourism Research, 14(5), 485-494. doi:10.1002/jtr.882

Kacen, J. J., \& Lee, J. A. (2002). The influence of culture on consumer impulsive buying behavior. Journal of Consumer Psychology, 12(2), 163-176. doi:10.1207/S15327663/CP1202_08

Kantsperger, R., \& Kunz, W. H. (2010). Consumer trust in service companies: A multiple mediating analysis. Managing Service Quality, 20(1), 4-25.

Kirkman, B. L., Lowe, K. B., \& Gibson, C. B. (2006). A quarter century of culture's consequences: A review of empirical research incorporating Hofstede's cultural values framework. Journal of International Business Studies, 37(3), 285-320. doi:10.1057/palgrave. jibs. 8400202

Kumar, N., \& Scheer, L. K., \& Steenkamp, J-B. E. M. (1995). The effects of perceived interdependence on dealer attitudes. Journal of Marketing Research, 32(3), 348-356. doi:10.2307/3151986

Kwortnik, R. J. (2008). Shipscape influence on the leisure cruise experience. International Journal of Culture, Tourism and Hospitality Research, 2(4), 289-311. doi:10.1108/17506180810908961

Lee, C-K., Yoon, Y-S., \& Lee, S-K. (2007). Investigating the relationships among perceived value, satisfaction, and recommendations: The case of the Korean DMZ. Tourism Management, 28(1), 204-214. doi:10.1016/j.tourman.2005.12.017

Li, X., \& Petrick, J. F. (2008). Examining the antecedents of brand loyalty from an investment model perspective. Journal of Travel Research, 47(1), 25-34. doi:10.1177/0047287507312409

Li, X., \& Petrick, J. F. (2010). Towards an integrative model of loyalty formation: The role of quality and value. Leisure Science, 32(3), 201221. doi:10.1080/01490401003709123

Liu, B. S-C., Furrer, O., \& Sudharshan, D. (2001). The relationship between culture and behavioral intention toward services. Journal of Service Research, 4(2), 118-129. doi:10.1177/109467050142004

Matos, C. A., \& Leis, R. P. (2013). The antecedents of complaint behaviour for Brazilian and French consumers of services. International Journal of Consumer Studies, 37(3), 327-336. doi:10.1111/ijcs.12002

McMullan, R., \& Gilmore, A. (2008). Customer loyalty: An empirical study. European Journal of Marketing, 42(9-10), 1084-1094. doi:10.1108/03090560810891154

McSweeney, B. (2002). Hofstede's model of national cultural differences and their consequences: A triumph of faith-a failure of analysis. Human Relations, 55(1), 89-118. doi:10.1177/0018726702551004
Moliner, M. A., Sánchez, J., Rodríguez, R. M., \& Callarisa, L. (2007). Perceived relationship quality and post-purchase perceived value: An integrative framework. European Journal of Marketing, 41(11-12), 1392-1422. doi:10.1108/03090560710821233

Oh, H. (2000). The effect of brand class, brand awareness, and price on customer value and behavioural intentions. Journal of Hospitality \& Tourism Research, 24(2),136-162. doi:10.1177/109634800002400202

Oliver, R. L. (1997). Satisfaction: A behavioral perspective on the consumer. New York: McGraw-Hill.

Oliver, R. L. (1999). Whence consumer Loyalty?. Journal of Marketing, 63(SI), 33-45. doi:10.2307/1252099

Oppermann, M. (2000). Tourist destination loyalty. Journal of Travel Research, 39(1), 78-84. doi:10.1177/004728750003900110

Parasuraman, A., Zeithaml, V. A., \& Berry, L. L. (1988). SERVQUAL: A multiple-item scale for measuring consumer perceptions of service quality. Journal of Retailing, 64(1), 12-40.

Parola, F., Satta, G., Penco, L., \& Persico, L. (2014). Destination satisfaction and cruiser behaviour: The moderating effect of excursion package. Research in Transportation Business \& Management, 13, 53-64. doi:10.1016/j.rtbm.2014.11.001

Petrick, J. F. (2002). Development of a multi-dimensional scale for measuring the perceived value of a service. Journal of Leisure Research, 34(2), 119-134

Petrick, J. F. (2004). The roles of quality, value, and satisfaction in predicting cruise passengers' behavioral intentions. Journal of Travel Research, 42(4), 397-407. doi:10.1177/0047287504263037

Port of Barcelona. (2014). Corporate report 2013. Retrieved from http:// www.portdebarcelona.cat/en/web/autoritat-portuaria/memoriavigente

Reimann, M., Lünemann, U. F., \& Chase, R. B. (2008). Uncertainty avoidance as a moderator of the relationship between perceived service quality and customer satisfaction. Journal of Service Research, 11(1), 63-73. doi:10.1177/109467050831909

Rousseau, D. M., Sitkin, S. B., Burt, R. S., \& Camerer, C. (1998). Not so different after all: A cross-discipline view of trust. Academy of Management Review, 23(3), 393-404. doi:10.5465/amr.1998.926617

Ryu, K., Han, H., \& Kim, T.-H. (2008). The relationships among overall quick-casual restaurant image, perceived value, customer satisfaction, and behavioral intentions. International Journal of Hospitality Management, 27(3), 459-469. doi:10.1016/j.ijhm.2007.11.001

Sánchez, J., Callarisa, L., Rodríguez, R. M., \& Moliner, M. A. (2006). Perceived value of the purchase of a tourism product. Tourism Management, 27(3), 394-409. doi:10.1016/j.tourman.2004.11.007

Santos, P. M. F., \& Porto, R. B. (2014). Responsabilidade ambiental e lealdade de clientes em banco de varejo. RAE-Revista de Administração de Empresas, 54(6), 606-618. doi:10.1590/s0034759020140602

Sirdeshmukh, D., Singh, J., \& Sabol, B. (2002). Consumer trust, value, and loyalty in relational exchanges. Journal of Marketing, 66(1), 15-37.

Soares, A. M., Farhangmehr, M., \& Shoham, A. (2007). Hofstede's dimensions of culture in international marketing studies. Journal of Business Research, 6o(3), 277-284. doi:10.1016/j. jbusres.2006.10.018

Stolz, J., Molina, H., Ramírez, J., \& Mohr, N. (2013). Consumers' perception of the environmental performance in retail stores: An 
analysis of the German and the Spanish consumer. International Journal of Consumer Studies, 37(4), 394-399. doi:10.1111/ ijcs.12028

Sweeney, J. C., \& Soutar, G. N. (2001). Consumer perceived value: The development of a multiple item scale. Journal of Retailing, 77(2), 203220. doi:10.1016/So022-4359(01)00041-0

Tian-Cole, S., Crompton, J., \& Wilson, V. (2002). An empirical investigation of the relationship between service quality, satisfaction and behavioral intentions among visitors to a wildlife refuge. Journal of Leisure Research, 34(1), 1-24.

Tipton, F. B. (2009). Modeling national identities and cultural change: The Western European, Japanese, and United States experiences compared. International Journal of Cross Cultural Management, 9(2), 145-168. doi:10.1177/1470595809335722

Trompenaars, F. (1997). Riding the waves of culture: Understanding cultural diversity in business. London: Nicholas Brealey.

Tse, D. K., \& Wilton, P. C. (1988). Models of consumer satisfaction: An extension. Journal of Marketing Research, 25(2), 204-212. doi:10.2307/3172652

Varki, S., \& Colgate, M. (2001). The role of price perceptions in an integrated model of behavioral intentions. Journal of Service Research, 3(3), 232-240. doi:10.1177/109467050133004
Williams, P., \& Soutar, G. N. (2009). Value, satisfaction and behavioral intention in an adventure tourism context. Annals of Tourism Research, 36(3), 413-438. doi:10.1016/j.annals.2009.02.002

Wong, N. Y. (2004). The role of culture in the perception of service recovery. Journal of Business Research, 57(9), 957-963. doi:10.1016/ s0148-2963(03)00002-x

Xie, Y., \& Peng, S. (2009). How to repair customer trust after negative publicity: The roles of competence, integrity, benevolence, and forgiveness. Psychology \& Marketing, 26(7), 572-589. doi:10.1002/ mar.20289

Yoon, Y., \& Uysal, M. (2005). An examination of the effects of motivation and satisfaction on destination loyalty: A structural model. Tourism Management, 26(1), 45-56. doi:10.1016/j.tourman.2003.08.016

Yuksel, A., Kilinc, U. K., \& Yuksel, F. (2006). Cross-national analysis of hotel customers' attitudes toward complaining and their complaining behaviors. Tourism Management, 27(1), 11-24. doi:10.1016/j. tourman.2004.07.007

Zielke, S. (2010). How price image dimensions influence shopping intentions for different store formats. European Journal of Marketing, 44(6), 748-770. doi:10.1108/03090561011032702 